\title{
The role of European National Forest Inventories for international forestry reporting
}

\author{
Claude Vidal $^{1}$ (D) Iciar Alberdi $^{2} \cdot$ John Redmond $^{3} \cdot$ Martin Vestman $^{4} \cdot$ Adrian Lanz $^{5}$. \\ Klemens Schadauer ${ }^{6}$
}

Received: 24 February 2015 / Accepted: 8 March 2016/Published online: 18 April 2016

(C) INRA and Springer-Verlag France 2016

\begin{abstract}
- Key message Despite agreements on definitions, the national data provided for international reporting are lacking comparability. To address this limitation the European National Forest Inventory Network has established criteria to harmonise definitions and to provide tools to transform national data into internationally comparable data.

- Context Forest reporting presents a series of challenges for countries, owing to diverse processes at international level such as the Global Forest Resources Assessment
\end{abstract}

Handling Editor: Jean Daniel Bontemps

Contributions of the co-authors Claude VIDAL: coordination, data analysis and writing of manuscript

Iciar ALBERDI: designing schemes and writing of manuscript

John REDMOND: checking the consistency and writing of manuscript,

English edition

Martin VESTMAN: data analysis, writing of manuscript

Adrian LANZ: checking the consistency and proposing a new template of the article

Klemens SCHADAUER: checking the consistency and writing of the manuscript.

Claude Vidal

claude.vidal@jrc.ec.europa.eu; claudevidal2@gmail.com

Iciar Alberdi

alberdi.iciar@inia.es

John Redmond

JohnJ.Redmond@agriculture.gov.ie

Martin Vestman

martin.vestman@slu.se

Adrian Lanz

adrian.lanz@wsl.ch

Klemens Schadauer

klemens.schadauer@bfw.gv.at
(FRA), Convention on Biological Diversity, United Nations Framework Convention on Climate Change and its Kyoto Protocol. Further challenges are faced at European level with Forest Europe and policy needs.

- Aims The aim of this paper is to provide a comprehensive review of the national and international forest reporting processes and of the role of the National Forest Inventories (NFIs) and the long-associated challenges resulting from a lack of comparability in definitions used. In addition, there is a discussion on the role of the European National Forest Inventory Network (ENFIN) as a facilitator for enhancing harmonization and comparability of national data and the ancillary information required to monitor European forestry-related policies.

- Methods NFIs take part to international reporting processes as providers of information. They are correspondent to the FRA process, and then they know very well the context of harmonization. Participating in the ENFIN research projects,

1 JRC-Forest Resources and Climate Unit-Institute of Environment and Sustainability, Via Enrico Fermi I, 21027 Ispra, VA, Italy

2 INIA-CIFOR. Dpto. Selvicultura y Gestión de los Sistemas Forestales, Ctra. La Coruña km. 7.5, 28040 Madrid, Spain

3 Department of Agriculture, Food and the Marine, Johnstown Castle Estate, Wexford, Ireland

4 Swedish University of Agricultural Sciences (SLU), SE 90183 Umeå, Sweden

5 Swiss Federal Research Institute, Zürcherstrasse 111, 8903 Birmensdorf, Switzerland

6 Department for Forest Inventory, Austrian Research Centre for Forests, BFW, 1131 Vienna, Austria 
NFIs, and particularly authors, conducted a screening exercise on harmonization status at European and World level.

- Results This review article is a synthesis of the main findings of the abovementioned screening exercise. It highlights the main gaps in terms of comparability of result in international reporting. Thanks to ENFIN harmonization research project, it gives same ways of working as a possible benchmark for the rest of the world.

- Conclusion Based on the international reporting exercises, their interactions, and impacts on new forestry policy requirements, the need for a strengthened harmonization process can clearly be demonstrated. Due to European policy needs, research work within ENFIN has been initiated to develop tools for building comparable results at international level. This work is an important benchmark particularly for countries outside Europe from which to base future harmonization work.

Keywords Forest · Wood resources · Harmonization . International reporting exercises $\cdot$ European National Forest Inventory Network

\begin{tabular}{|c|c|}
\hline \multicolumn{2}{|c|}{ Abbreviations } \\
\hline NFIs & National Forest Inventories \\
\hline ENFIN & European National Forest Inventory Networl \\
\hline $\mathrm{AO}$ & $\begin{array}{l}\text { Food and Agriculture Organization of the } \\
\text { United Nations }\end{array}$ \\
\hline FRA & Forest Resource Assessments \\
\hline NCED & $\begin{array}{l}\text { United Nations Conference on Environment } \\
\text { and Development }\end{array}$ \\
\hline UNFCCC & $\begin{array}{l}\text { United Nations Framework Convention on } \\
\text { Climate Change }\end{array}$ \\
\hline UNCCD & $\begin{array}{l}\text { United Nations Convention to Combat } \\
\text { Desertification }\end{array}$ \\
\hline GHG & $\begin{array}{l}\text { Convention on Biological Diversity (CBD), } \\
\text { greenhouse gas }\end{array}$ \\
\hline ITTO & International Tropical Timber Organization \\
\hline FIs & National Forest Inventories \\
\hline COST & $\begin{array}{l}\text { European Cooperation in Science and } \\
\text { Technology }\end{array}$ \\
\hline C\&I & Forest Europe Criteria and Indicators \\
\hline SFM & Sustainable Forest Management \\
\hline CFRQ & Collaborative Forest Resources Questionnai \\
\hline UNEP & United Nations Environment Programme \\
\hline UN & United Nations \\
\hline OFAC & Observatoire des Forêts d'Afrique Centrale \\
\hline COMIFAC & Commission des Forêts d'Afrique Centraler \\
\hline FRA RSS & $\begin{array}{l}\text { Forest Resources Assessment Remote sensin } \\
\text { survey }\end{array}$ \\
\hline LBA & a Legally Binding Agreement \\
\hline $\mathrm{NC}$ & Intergovernmental Negotiating Committee \\
\hline EFI & European forest Institute \\
\hline
\end{tabular}

REDD+ Reducing Emissions from Deforestation and forest Degradation processes

EC European Commission

JRC Joint Research Centre

FC Framework Contract

EP European Parliament

MS Member States

EFDAC European Forest Data Centre

EFFIS European Forest Fire Information System

FISE Forest Information System for Europe

EFBN European Forest Bureau Network

\section{Introduction}

In recent decades, the focus on forestry and forest management has shifted from being primarily focused on wood production to sustainable ecosystem management. Therefore, the scope of National Forest Inventories (NFIs) has broadened to include new variables to meet these new information requirements (Tomppo et al. 2010a). This concerns reporting at both national and international level. This broadened scope is a huge challenge for NFIs in terms of definitions and methodology. The term "definitions" must be understood for all the variables collected by NFIs for national purposes and international reporting. It applies from forest and forest area to deadwood and forest composition going through growing stock, biomass, increment, fellings but also browsing impact or variables related with non-wood forest products (NWFP). Concerning "methodology", this term covers remote sensing (RS) techniques as well as ground surveys, both in statistical terms including sampling design, estimation methods and precision attached to the results. Models for estimating wood resources and biomass from the collected variables such as tree height and diameter at breast height are also part of these methodology aspects.

The European National Forest Inventory Network (ENFIN) was established to promote NFIs as comprehensive monitoring systems by harmonising information on forest ecosystems. "Harmonization" in terms of NFIs is the process of making data and estimates comparable over time and across administrative borders. At European level, NFIs decided to join efforts to exchange information, methods and to work more closely together to set up new statistical tools and new models. The group aims to enhance co-operation between organizations that implement NFI, the promotion of knowledge-sharing, enhancement of sampling methods and new assessment methodologies. This will lead to the continuous improvement of methods, data collection and data analysis within the NFIs. Since its foundation in 2003, a number of projects have been carried out under the ENFIN umbrella. With the aim of enhancing data harmonization for international reporting, the undertaken actions can be split into three 
different types: (i) research projects for proposing harmonization methodology; (ii) case studies in order to implement the results of research projects at national or regional level and (iii) knowledge sharing not only among European countries but also outside Europe. This regional effort (sensu regions of the world) may serve as a benchmark for other less harmonized regions of the world, by demonstrating methods, difficulties and perspectives in harmonising. Within all these projects, the harmonization methodology and some test case study results were produced. For example, for estimating growing stock (GS), the Swiss NFI measures only trees with a diameter at breast height greater or equal to $12 \mathrm{~cm}$ whereas this threshold is $0 \mathrm{~cm}$ for the reference definition of GS agreed under cost Action E43 (Lanz et al. 2010). Therefore, an estimate of the missing part of the Swiss GS is necessary to correspond with the reference definition.

\section{International forestry reporting}

\subsection{Food and Agriculture Organization of the United Nations}

The Food and Agriculture Organization of the United Nations (FAO) is charged with collecting, evaluating and disseminating information relating to nutrition, food and agriculture and associated areas such as forestry. In 1946, one year following the founding of FAO, a first global survey on forest and forestry aspects was conducted by the organization. The results were published in 1948 as Forest Resources of the World (FAO 1948). The assessment was based on a questionnaire sent to all countries, of which 101 responded, representing about 66 percent of the world's forests. The variables collected were the forest area (total and productive sensu mainly devoted to wood production), types of forest by accessibility, growth and fellings. This first world forest inventory report pointed out a lack of reliable forestry inventory information for many countries and a lack of commonly accepted terms and definitions.

Starting with the forest area and wood production, in line with the development focus at that time, the questionnaire evolved gradually to grasp environmental and social aspects of forest and forestry products in order to provide the population with a better quality of life. In the 1960s and early 1990s, the environmental functions of forests grew in importance. There was even a holistic perception of world forests as part of the "global ecosystem" (Food and Agriculture Organization 1995). New definitions were agreed, and new variables were collected to assess these environmental and social components, expanding the challenge of comparability between national collected data (Matthews 2001). Models were built to study global forests as a source or a sink of carbon in the atmosphere, depending on whether there is an increase or decrease in global forest biomass (Blackard et al. 2008). These national models generally using NFI data highlighted the discrepancies between carbon evaluations from one country to another one (Keith et al. 2009). After the Rio conference in 1992, the concept of sustainability which had been largely shared among foresters for centuries, gained importance on the political agenda at world level and sustainable forest management (SFM) came to the fore. Thus, new variables were collected in order to assess these aspects and their evolution over time (Castaneda 2000). Political debate on the variables to be included still exists, such as the ratio between harvest and production. Due to this difficulty, the concept has become a matter of political concern, and countries use different approaches to evaluate how SFM is implemented and achieved in their country (Mc Donald and Lane 2004).

\section{The forest resources assessment}

The FAO Forest Resources Assessment (FRA) has been assessing the world's forests at 5 to 10 year intervals since 1946. The FRA reporting process is functioning in four steps. The first step is an exchange between national correspondents (mainly NFI experts) and the FAO on definitions. This exchange includes discussion on new attributes and other proposed changes, as well as preparation of the next reporting exercise. The second part is the provision of data by countries. Then, the third step is an iterative interaction between FAO and the national correspondent on comprehension and consistency of these data. The last step is the analysis of data and production of the report by FAO.

There has been a long-standing scientific and technical consultation process between countries and FAO in order to improve definitions and enhance the comparability of data. Since 1987 onwards, an expert level meeting has been organised in Kotka (Finland), at approximately 6-year intervals, in order to analyze the results of the previous FRA process and to propose improvements in definitions for the next FRA exercise (Killmann and Schöne 2003). These harmonization exercises have three main goals: (i) to refine definitions where necessary, (ii) to improve the consistency and utility of the data and (iii) to ensure as far as possible the comparability of temporal series of forest data.

Nevertheless, the significant differences in forest types between tropical, temperate and boreal forests have repeatedly challenged harmonization problems. The harmonization work on definitions is a long-standing work which requires consensus. However, consensus may lead to a lack of clarity in the formulated definitions as the final definition had to cater for all the national needs (de Foresta et al. 2013). The vagueness introduced to the definitions opened the door to national interpretation resulting in heterogeneous data that was hardly comparable between countries (Matthews and Grainger 2002). In this 
respect, the FAO pushed countries to provide metadata on how variables were assessed. Important though this process was to understand the differences between countries in applying FAO common definitions. It did not open newer perspectives to the data because the countries continued to use their national interpretation of the definitions (Kelatwang 2002). In addition to this national interpretation of FAO definitions, it is necessary to have an insight into the diversity of tools used to collect data. Some countries have long-standing NFIs; others started recently to implement a NFI and some others only use remote sensing (RS) surveys. Thus, the quality of data, estimations and level of precision are quite different among them (Hansen et al. 2013). For the countries only using RS surveys, some variables such as the forest area change, growing stock or biomass are sometimes difficult to estimate, particularly if there is no field assessment and precision estimates are rarely available (Grainger 2008; Romijn et al. 2015).

The situation has improved over time and in 2014, 112 countries implemented NFI programmes (more than two thirds of the total number of countries participating in the FRA exercise) offering the possibility to give a reliable estimation of quantitative variables with attached statistical errors. These countries include some of the 77 percent of the world's forest area assessed with at least a first comprehensive NFI assessment established or running (Keenan et al. 2015). The number of countries implementing new statistical NFIs in recent times includes Hungary (2010) and Russia (2007). Also, during 2015, Bulgaria started the planning phase for a new statistical NFI.

In 1990, the FAO introduced a remote sensing survey (RSS) at world level (FRA RSS) with the support of the Joint Research Centre (JRC) of the European Commission (EC) to assess sustainable forest management (SFM) and produce data mainly for parts of the world where NFIs were not in place at that time. This FRA RSS is conducted every 10 years for assessing the forest area and forest area changes. The survey is composed of over 13,000 sampling blocks of $10 \times 10 \mathrm{~km}$ within Landsat images. Other large RSS used wall-to-wall sets of Landsat images with comparable results to the ones obtained by the FRA RSS (Gong et al. 2013; Hansen et al. 2013) or also MODIS images (Hansen et al. 2010). The use of different forest definitions produces varying estimates of the forest area. For example, the FRA uses a land-use definition (FRA 2015) while the FRA RSS uses a land cover one (FAO 2012). Hansen et al. (2013) estimate the forest area changes in a different way by measuring tree cover changes. The results are quite similar, and an analysis of the differences in results using these different methods can be found in Keenan et al. (2015).

Definitions of some terms have evolved, such as the definition of forest, for example (Putz and Redford 2010). Additional new variables and then definitions appeared. This aspect adds a supplementary difficulty in terms of continuity of data series. In particular, the evaluation of changes using different surveys over time has to be very carefully considered.

\subsection{The Rio Summit}

The United Nations Conference on Environment and Development (UNCED), also known as the Rio (or Earth) Summit, was a major United Nations conference focussing on environmental challenges at a global level (UN 1992). The Earth Summit resulted in important documents such as: The Rio Declaration on Environment and Development, the Agenda 21 and the Forest Principles. Moreover, important legally binding agreements were opened for signature: the Convention on Biological Diversity (CBD), the United Nations Framework Convention on Climate Change (UNFCCC) and the United Nations Convention to Combat Desertification (UNCCD). From the Earth Summit, international agreements such as the CBD (2010) and the Kyoto Protocol (1997), with mandatory reporting exercises and different goals, enhanced the necessity for countries to report on the state and changes of forest resources. All these new reporting processes have increased the necessity for comparable information, but this has been particularly difficult when the definitions differ between obligations. Below, the most important treaties or documents that engage with NFI processes are described.

\section{- The Convention on Biological Diversity}

The Convention on Biological diversity (CBD) is an international legally binding treaty (Rio Conference 1992). Its objective is to develop national strategies for the conservation and sustainable use of biological diversity. Its reports are often seen as the key documents regarding sustainable development. There are 194 parties to the CBD and 183 national action plans.

During the tenth Conference of the Parties (COP) held in Aichi, Japan, in 2010, the CBD adopted Decision X/2 for the implementation of the strategic plan for biodiversity 2011/2020 and established the 20 Aichi targets (Chirici et al. 2012). In 2010, the Aichi targets were established with a view to reducing the rate of biodiversity loss and averting dangerous biodiversity change (Pereira et al. 2013). Target 5 requires that the loss of all natural habitats, including forests, is halved and, if feasible, stopped while target 7 requires that the areas under agriculture, aquaculture and forestry be sustainably managed, thus ensuring conservation of biodiversity (CBD 2010 in Chirici et al. 2012).

Member states (MS) reports include a qualitative description of the forest. It is noteworthy, that the Article 11 and 17 reporting of the Flora-Fauna-Habitat Directive forms an indirect reporting linked to the CBD for EU countries. Information submitted is used to inform at regional and global level analyzes of 
environmental status and to evaluate the success of actions and indicate areas in which more action may need to be taken or new policies developed (Mohammadi Fazel et al. 2015).

\section{- The United Nations Framework Convention on Climate Change}

The UNFCCC is an international environmental treaty with the objective to "stabilize greenhouse gas (GHG) concentrations in the atmosphere at a level that would prevent dangerous anthropogenic interference with the climate system" (UNFCCC 2009). The convention provides a framework for negotiating specific international treaties (called "protocols") that may set binding limits on greenhouse gases. As a follow-up, the Kyoto Protocol was signed in 1997, establishing legally binding obligations for the developed countries to reduce their GHG emissions. A 1990 benchmark level was calculated, as the starting point for the commitment of those countries to GHG reductions. Actions taken by the developed and developing countries to reduce emissions include support for renewable energy, improving energy efficiency and reducing deforestation. Updated inventories on GHG emissions must be annually submitted in order to check if countries are in line with their obligations. Forests play an important role in GHG emissions during deforestation, logging or natural hazards and as GHG sinks for the other aspects of forest growth and management. In some cases, NFIs adapted their collection of data and in some countries even the surveys in order to provide the necessary annual data for reporting to the UNFCCC from the forest sector (Dolman et al. 2013).

- The United Nations Convention to Combat Desertification

The United Nations Convention to Combat Desertification (UNCCD) is a legally binding international agreement linking the environment and the development of sustainable land management. The UNCCD concerns specifically the arid, semi-arid and dry sub-humid areas in the world, known as the dryland. These areas contain some of the most fragile ecosystems and societies (Trumper et al. 2008). The UNCCD is promoting both the prevention of land and forest degradation through sustainable land and forest management practices and the restoration of already degraded land and forests. Evaluations of land cover changes and forest degradation for this reporting exercise are mainly obtained through RS using a time series of successive images. In the absence of specific monitoring, this evaluation is more accurate when NFI data is available (The World Bank 2008) and if there is not a specific monitoring system.

\section{- The Forest Principles}

It is the informal name given to the Non-legally Binding Authoritative Statement of Principles for a Global Consensus on the Management, Conservation and Sustainable Development of all types of forests. It makes several recommendations for conservation and sustainable development of forests (Johnson 1993).

\subsection{International requirements for "regions" of the world}

Concerning the forest and forestry aspects, according to $\mathrm{UN}$ and intergovernmental agreements, the world is divided in different zones called regions by the FAO with some organizations set up to deal with common problems (Fig. 1). These organizations have different goals and statuses. Examples of such organizations and mandates are listed in the following paragraphs.

\section{- The United Nations Economic Commission for Europe}

The United Nations Economic Commission for Europe (UNECE), through its Forestry and Timber Section, has served as a definitive source of information about temperate and boreal forests. This information has described the forest sector in the UNECE region for more than 50 years as the Temperate and Boreal Forest Resources Assessment (TBFRA). This organization is working mainly with countries that have a NFI to provide data. As a consequence, the discussions are more advanced than for other parts of the world in terms of harmonization of definitions, knowledge sharing on sampling design, production of metadata and data comparability (Gold et al. 2006). It operates to a mandate agreed by the 56 countries, which together comprise the UNECE region, stretching from North America to the Russian Federation and Central Asia. At pan-European level, the UNECE Forestry and Timber section has worked for years on the harmonization of definitions and data. A Team of Specialists (ToS) on TBFRA, which encompassed associate NFI experts and the United Nations (UN) Secretariat, was set up in June 1993. Each ToS has a limited mandate which is discussed and reformulated every 4 years to focus on UN priorities. The TBFRA ToS focused on temperate and boreal $\mathrm{UN}$ forest reporting activities until the year 2000 (FRA 2000; UNECE/FAO 2000b). In 2002, with no more specific production of data for the UNECE region, the harmonization work continued together with the FAO to progress the improvement of concepts and definitions as well as interpretation of results. From April 2008, the mandate of this ToS turned to monitoring SFM. The results of this work allow for regular critical assessment of the health and sustainability of Europe's forests to be made, using criteria and indicators drawn up by the countries active in the Forest Europe process.

\section{- The Montréal Process}

This process was also known at the beginning as the Working Group on Criteria and Indicators for the Conservation and Sustainable Management of Temperate and Boreal Forests. It started in 1994 as a result of the Forest Principles. It is an intergovernmental response to the pressing need for sustainable forest 


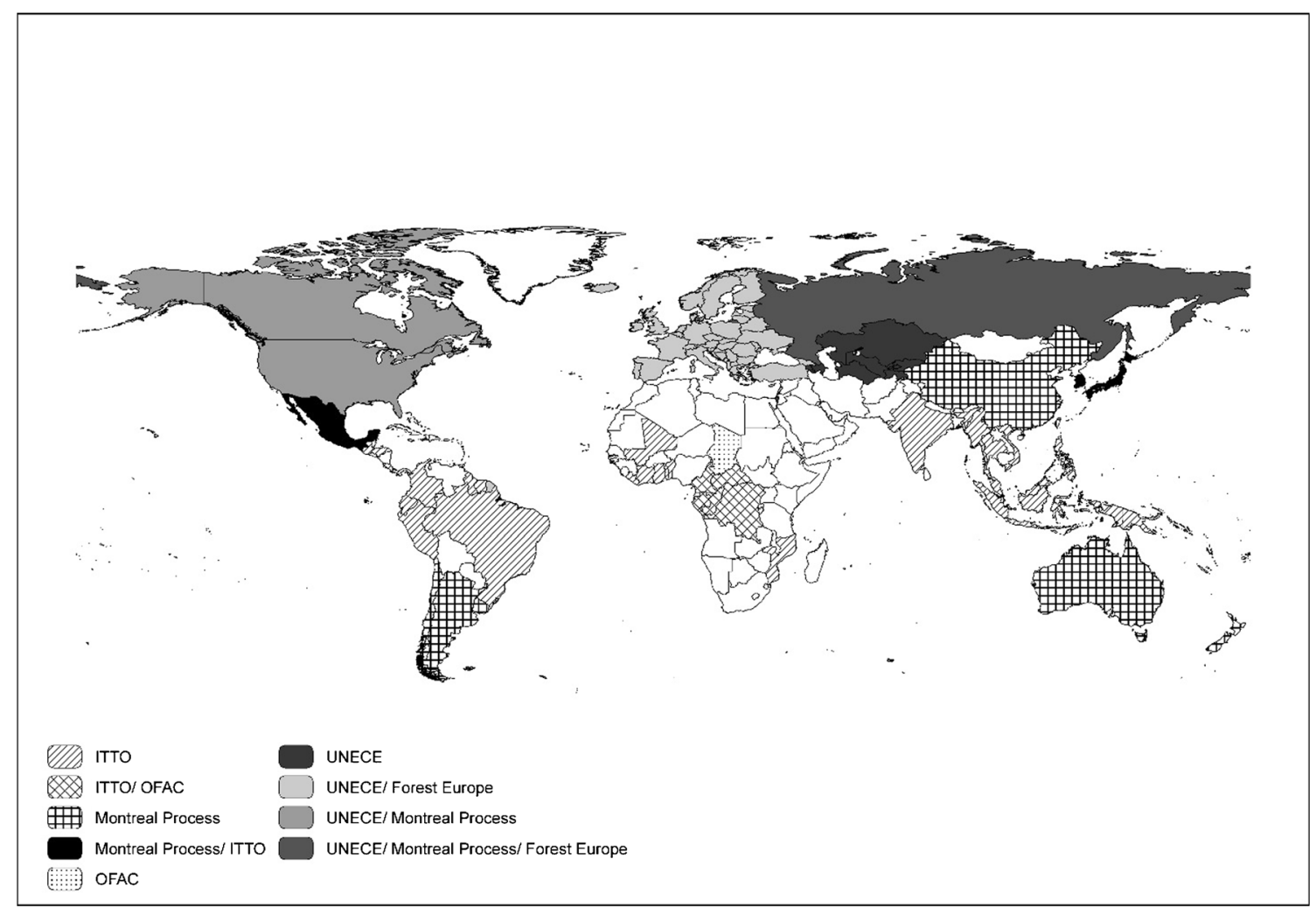

Fig. 1 Map of the different international organizations

management. The Montréal Process countries include; Argentina, Australia, Canada, Chile, China, Japan, Korea, Mexico, New Zealand, Russian Federation, USA and Uruguay (Canadian Forest Service 1997). This process could be seen as a counterpart to the Ministerial Conference on the Protection of Forests in Europe (MCPFE) for the American/Asian zone. It established its own set of criteria and indicators to assess SFM. Through this process, member countries continue to make a voluntary commitment to work alongside each other to foster the sustainable management of their forests and to create a pathway for collaboration and capacity building. NFIs are closely and strongly involved in this process to provide data, prepare reports and data analysis. This interaction facilitates harmonization work between participating NFIs.

\section{- The Observatoire des Forêts d'Afrique Centrale}

The Observatoire des Forêts d'Afrique Centrale (OFAC) is an association of public and private bodies, researchers and NGOs whose goal is to help set up the convergence plan of Commission des Forêts d'Afrique Centrale (COMIFAC). It will provide COMIFAC and country members a powerful steering and national or RS data sharing platform to promote better governance and the sustainable management of forest ecosystems. These countries rely mainly on $\mathrm{RS}$ data for estimating the forest areas and forest resources. NFIs do not exist in a lot of countries in this region or at least are not yet implemented. The approach adopted for the creation of OFAC, which relies on human resources in the region, makes the development of OFAC a true exercise in capacity building at both national and regional levels. The principal data providers will be COMIFAC and its institutional partners, the ministries responsible for forest management and the environment, the private sector, protected areas management, forest management, NGOs, international projects, research institutions, universities, etc. Within the observatory, some projects play the role of facilitator for the collection, harmonization and dissemination of information.

\section{- International Tropical Timber Organization}

The International Tropical Timber Organization (ITTO) is an intergovernmental organization promoting the conservation and sustainable management, use and trade of tropical forest resources. It develops internationally agreed policy documents to promote sustainable forest management and forest conservation. It assists tropical member countries to adapt such policies to local circumstances and to implement them in the field through projects. The ITTO also collects analyzes and disseminates data on the production and trade of tropical timber.

All these international processes used their own definitions in line with their particular goals, so small differences existed 
between reporting exercises and the burden of countries was very high. In 2012, a convergence process between international processes and national correspondents, initiated by FAO, made some proposals in order to avoid too much burden to the providers of information and to capitalize on the central focal point which is the FRA report. With the same aim, concordance of dates was also decided. The majority of data is now collected using a Collaborative Forest Resources Questionnaire (CFRQ) and only a part of data concerning each regional process is added.

\section{European forestry policy needs}

\subsection{European Union level}

The European Union (EU), as an international organization, has signed all the UN agreements endorsed by its Member States (MS). Therefore, the EU also has to report as an entity for UN processes such as the CBD or the Kyoto protocol. As a consequence, the European Commission (EC) sets up actions for collecting data and building models at EU level in order to provide such answers to international LBA (EC 2009). Harmonization is crucial for the EU to ensure that EU figures are compliant with the sum of results of its MS.

Even if there is no mandate for working with forest issues directly and no coherent forest policy at EU level, forests are indirectly part of several main EU policies and legislation as highlighted in the EU forest strategy (EC 2013). Forests are an integral component of the "Habitats and Birds Directives", about $46 \%$ of the Natura 2000 surfaces are covered by forest ecosystems (EEA 2012) and the Biodiversity Strategy 2020 has several targets where forests are specifically mentioned. The EU supports SFM and the multifunctional role of forests as expressed in the EU Forest Action Plan and the Forest Strategies. Forests also play an important role in other existing EU policies, such as energy policy (Renewable Energy Directive/2009/28/EC) and Reducing Emissions from Deforestation and forest Degradation and rural development legislation (REDD+). There is a continued need for forest indicators and assessments at EU level to support the development and implementation of a number of European environmental policies, where forests play a major role. The European Commission (EC) collects data on forestry aspects through Eurostat and its statistical network, but these data are mainly socio-economic variables. Data coming from NFIs are sourced from the FRA process and from the State of Europe Forests (SoEF) at European level. The EC tried to obtain more information from NFIs but with little success due to the lack of a common forest policy. NFIs were funded by countries for national purposes, and forest is considered part of the subsidiarity principle. Now, the situation is evolving because the EC, the MS and the European Parliament (EP) have stressed the necessity for a better harmonized dataset at EU level (EC 2013).

The political issues that NFIs have to address are the following:

- How is the forest resource in Europe developing when different policy goals related to forests are implemented?

- Is it possible to ensure a sustainable provision of ecosystem services from forests even though climate change and social pressures increase?

- What are the consequences for forest management when implementing one or more forest related policy?

- What are the trade-offs in forest development and in the provision of the various services of forests when favouring one forest related policy goal over another: e.g., more biodiversity vs. more resources for energy?

A large consultation process was launched and the most important outcomes from EU institutions, Member States (MS), the research community, EU citizens and other interested stakeholders of this consultation were as follows (EC 2010):

1) There is a general interest in addressing forest information at EU level. A sizable majority of reactions argue for more harmonized and more readily available information about EU forests, forest production estimates, biodiversity in forests, carbon accounting, valuation of non-timber forest services and goods, etc.;

2) More research efforts are needed to establish adequate knowledge about the nature, extent and expected effects of climatic change on forests and the forest sector;

3) Forests in the Mediterranean region are likely to be most affected by climate change, followed by the mountainous and Central European forests (mostly coniferous).

To address these questions, intensive monitoring on the status of forests is required, which goes beyond the borders of countries. Harmonizing data produced at national level and developing information systems to collect and analyze the results, is fundamental to the production of sound EU forest information. In this respect, the Standing Forestry Committee (SFC) has set up an ad hoc working group (WG) on data availability at national level, how to use it for EU purposes and how far it is possible to harmonize these data and results. The conclusions of this ad hoc WG stressed (i) the importance of NFIs in this process of production and harmonization of information and (ii) the role that NFIs should play in the future for discussing feasibility of new data and Criteria and Indicators (C\&I) for EU policy needs (EC 2012).

\subsection{Pan-European process}

On the initiative of France and Finland, the First Ministerial Conference on the Protection of Forests in Europe (MCPFE) was held in Strasbourg in 1990. The Strasbourg Conference was 
a major step to initiate the incorporation of scientific data into political action to protect Europe's forests. After the Earth Summit, the Second Ministerial Conference, held in Helsinki in June 1993 adopted four resolutions reflecting Europe's approaches to global environmental issues; namely the promotion of sustainable forest management, the conservation of biological diversity, strategies regarding the consequences of possible climate change for the forest sector and increasing co-operation with countries in transition to market economies (Barthod and Touzet 1994). At the Lisbon Conference in 1998, the ministers decided to develop a work programme including a set of Criteria and Indicators (C\&I) to check the sustainability of Forest Management at pan-European level (MCPFE 1998). A set of 35 C\&I was endorsed at the Vienna conference in April 2003 (MCPFE 2003). The majority of data are now collected using the CFRQ, and only a specific part of results concerning the pan-European process is added. The MCPFE process took the name of "Forest Europe" under the leadership of Norway (2007-2011). In the general declaration, it is stated that "European expanding forests play an important role in mitigating climate change. SFM promotes the conservation of biodiversity. However, diseases and extreme weather conditions like storms and fires also threaten forests. Europe's forests provide renewable wood for processing and energy, thereby fostering a green economy" (Forest Europe, UNECE and FAO 2011). With this summary, the State of Europe's Forests 2015 (Forest Europe,UNECE and FAO 2015) report provides a complete assessment of the entire forest estate, through 35 quantitative and 17 qualitative indicators. The qualitative includes five indicators providing general information about the forest area governed in a country and 12 indicators providing information about policies, institutions and instruments used to address specific topics. This ongoing process stressed the need (i) to check consistency of NFI data together with socioeconomic information, (ii) verify reliability and comparability of the information provided and (iii) assess robustness of changes over time and how far it is sound to interpret them.

After 25 years of producing and publishing C\&I reports, a screening exercise on the usefulness of these C\&I for SFM was launched in 2012. Concerning the C\&I effectiveness at national level, a study was financed by Germany and the work was allocated to the European Forest Institute (EFI). This study involves countries and international organizations. Several issues and some improvements and possible changes were raised (Baycheva et al. 2013):

1) More political will and commitment was needed;

2) A cost-effective mechanism to collect and analyze the information structured according to the indicators was required;

3) The cost-benefit ratio of implementation is not favourable for some of the indicators and this required further exploration;

4) However, the cost and consequences of not implementing the C\&I for SFM should also be taken into consideration;
5) The idea of composite indicators was highlighted, focusing on the need to measure progress of specific policy issues (e.g. biodiversity, profitability or protection).

\section{European NFIs as a benchmark to address harmonization issues}

\subsection{ENFIN}

The availability of relevant forest information is essential to the decision making process undertaken by forest managers and policy makers (Alberdi et al. 2014). NFIs are the primary source of forest information for most countries (Fig. 2). In many cases, the information provided by each NFI is closely linked to national legislation, particularly when forest and some related terms are defined by law. The information provided is guided by forest attributes, ecosystems and classifications in line with national history, geographic location, climatic conditions and biophysical characteristics. All NFI statistics are contained in databases, statistics from which are commonly disseminated in hard-copy and electronic formats. Furthermore, ecological characteristics and the cultural significance of plant species vary from territory to territory. As a result, difficulties exist in comparing information (Table 1) collected in different countries (Ferretti 2010; McRoberts et al. 2009).

The increasing workload at national level due to the many international information needs as well as information required on SFM at national level require clear information on definitions, data significance and limitations. The NFIs adopted different basic definitions and methodologies, leading to inconsistencies and lack of comparable data for international reporting (Gabler et al 2012). The data provision mechanisms must be based on a robust, statistically sound, current and long-term statistical information system. The ENFIN group collaborates with organizations such as Forest Europe, FAO, UNECE and the European Commission, which can benefit and be complementary to ENFIN's efforts. ENFIN serves a broad spectrum of forest-related policies and therefore aims to enhance co-operation between national forest inventory organizations, especially to: (i) provide a clearly visible platform for the provision of harmonized forest inventory information on European forests; (ii) promote knowledge-sharing, enhanced methods and new ideas; (iii) thereby maintain updated forest information systems; (iv) ensure continuous improvement of methods, data collection and data analysis within the NFI; (v) maximise the synergy between NFIs and other European and International level data collection systems, monitoring and reporting activities, and (vi) ensure openness to new requirements on forest data for emerging policy needs (EC 2013). 
Fig. 2 Role of National Forest Inventories in international reporting. White arrows indicate the organisations requiring information from NFIs while grey arrows show the international reports

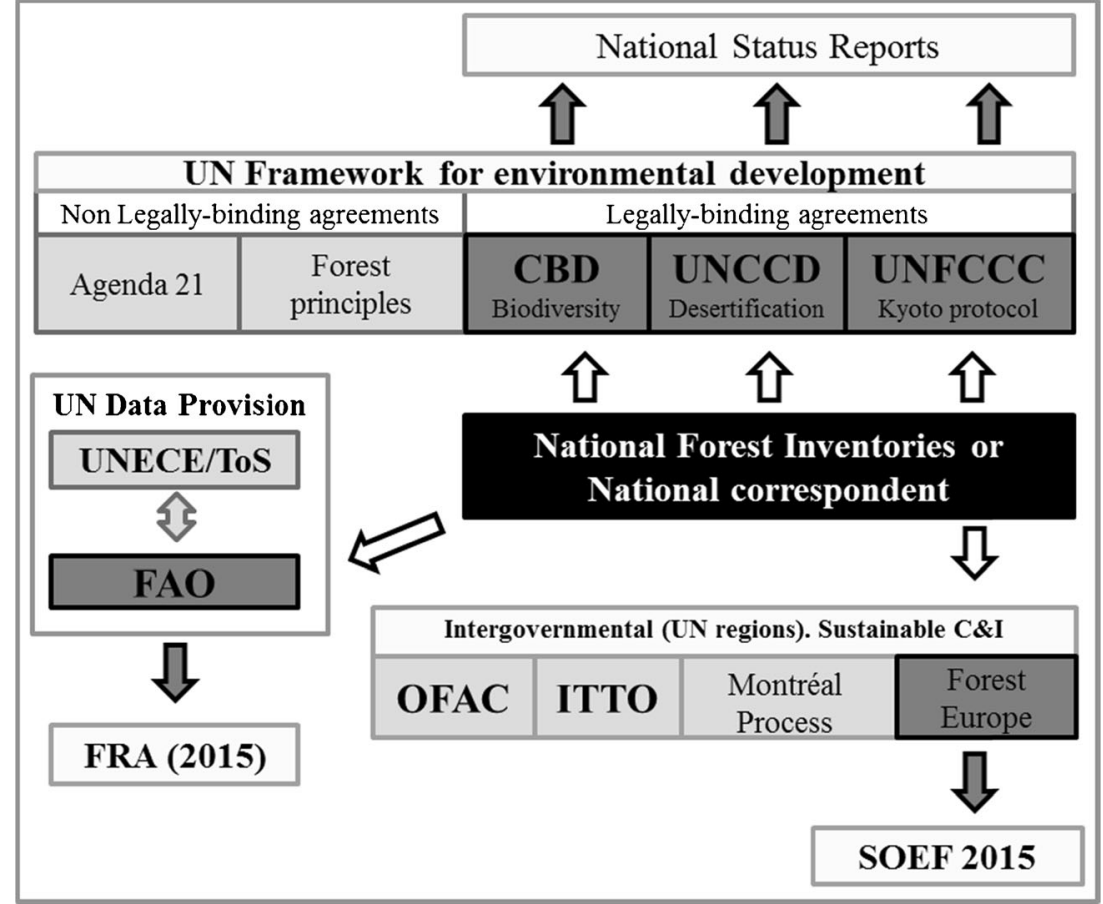

\subsection{COST harmonization research work and outputs}

Two COST research actions have been developed within the framework of ENFIN: "COST action E43" and "COST action FP1001 USEWOOD.”

\subsubsection{COST Action E43}

COST Action E43 was entitled "Harmonization of National Inventories in Europe: Techniques for Common Reporting". The main objective of the COST Action E43 was to improve and harmonize the existing national forest resource inventories in Europe. The secondary objectives were to support new inventories in such a way that inventories meet national, European and global level requirements in supplying up-to-date, harmonized and transparent forest resource information, and to promote the use of scientifically sound and validated methods in forest inventory designs, data collection and data analysis. More than 30 countries and institutions, mainly from Europe joined the Action, which was initiated in 2004. This harmonization effort has already gone beyond EU-members but is also of great interest outside Europe (McRoberts et al. 2012). It serves as a harmonization benchmark outside Europe. As examples, it is interesting to pinpoint
Table 1 Differences between forest definitions in international forestry reporting exercises

\begin{tabular}{lllll}
\hline Definition & Variable & $\begin{array}{l}\text { FRA } \\
(2000)\end{array}$ & $\begin{array}{l}\text { UNFCCC } \\
(2001)\end{array}$ & $\begin{array}{l}\text { UNEP/CBD/SBSTTA } \\
(2001)\end{array}$ \\
\hline $\begin{array}{l}\text { Considered areas in the } \\
\text { definition }\end{array}$ & $\begin{array}{l}\text { Young stands } \\
\text { Temporarily } \\
\text { unstocked areas }\end{array}$ & 1 & 1 & 1 \\
& Non-forest land uses & 1 & 1 & 0 \\
& Agroforestry & 1 & 0 & 1 \\
Variable thresholds & Min. area (ha) & 0.5 & $0.05-1.0$ & $\mathrm{n} / \mathrm{a}$ \\
& Min. height (m) & 5 & $2-5$ & 5.5 \\
& Crown cover (\%) & 10 & $10-30$ & 10 \\
& Strip width (m) & 20 & $\mathrm{n} / \mathrm{a}$ & $\mathrm{n} / \mathrm{a}$ \\
\hline
\end{tabular}

The considered forest areas in each definition ( 1 means it is considered while 0 means it is not) as well as the different thresholds used for the associated variables are shown

FRA Forest Resource Assessments, UNFCCC United Nations Framework Convention on Climate Change, $C B D$ Convention on Biological Diversity, $n / a$ not defined 
that (i) non-European countries such as the USA, Japan, South Korea, New Zealand and multiple international organizations such as FAO, UNECE; European Forest Institute (EFI), EC, EEA, and the Joint Research Centre (JRC) participated in meetings, (ii) numerous countries took part in the publication effort of providing country reports for the books published by SPRINGER for the COST E43 and COST Usewood exercises. They are Argentina, Brazil, Canada, Chile, China, Ecuador, Japan, New Zealand, Peru, the Republic of Korea, the Russian federation and the USA. The main objective was achieved through the development of agreed common inventory definitions. The Action developed and agreed upon "reference definitions" (Vidal et al. 2008) as the formal basis for harmonization. The methodological approach not only needs a reference definition but also a description of the full process involved. The general way of working includes an initial screening exercise of the state of the art. An enquiry is conducted by, e.g. a questionnaire in order to explore and highlight the differences between the definitions applied in the NFIs. The enquiry is followed by an analytical decomposition of these national definitions into criteria and a description of the differing national thresholds (Vidal et al. 2008). As an illustration, the example of an individual tree which is the basic entity for Growing Stock (GS) and biomass estimation can be taken. First, a reference definition of a tree is needed for the distinction from other woody plants. Second, unambiguous specifications of the elements or parts of a tree are required, because definitions related to GS and biomass estimation are usually formulated on the basis of tree parts to be considered. Thus, a reference definition of each tree element used for defining GS and biomass is also necessary. To establish a clear specification for each element, a multi-step analytical partitioning approach was proposed leading to the unambiguous definition of each tree element (Gschwantner et al. 2009). These tree elements are single disjoint parts of the tree that are clearly defined. Combined, these elements can describe a whole tree. In this way, a flexible scheme could be achieved that (i) serves as a basis for a broad range of reference definitions, (ii) permits further partitioning into additional, smaller elements and thus (iii) facilitates the adaptation to future developments and harmonization requirements. The accuracy and precision of this harmonized information is an essential point to be considered. It depends on many factors, e.g. the conciseness of the definitions involved, the availability and quality of data for developing and applying bridging functions, the ancillary information used and the method applied to perform the conversion from a national to a reference definition. An example applies for the Spanish NFI forest national definition with a minimum crown cover of $5 \%$ instead of $10 \%$ for the reference definition (Alberdi et al. 2010). The situation may be more complex when there are differences in more than one criteria involved. Another important example concerns forest biodiversity assessments (Winter et al. 2008; Winter et al. 2011).

Then, methods called "bridges" were developed to transform an estimate based on a local or national definition to correspond to a reference definition (Ståhl et al. 2012). There were three main outputs of this action: two books published by Springer, one of them describing each national NFI in depth (Tomppo et al. 2010b) and the other one describing the biodiversity assessments and harmonization with NFI information (Chirici et al. 2011) and a special issue of the scientific journal Forest Science published in 2012 (Vol 58). As an example of this harmonization work, an experimental test using deadwood data from 9208 sample plots measured in nine European countries and the United States was conducted (Rondeux et al. 2012).

\subsubsection{COST Action FP1001}

A new COST Action USEWOOD focusing on wood resources and wood supply harmonization was proposed and accepted in 2010. Its title was: "Improving data and information on the potential supply of wood resources: A European approach from multisource National Forest Inventories". The question of wood availability in Europe on a sustainable basis is highly relevant to define global climate change mitigation strategies and targets for biomass energy as adopted at national and European level, and to support the proposal of an increased use of wood as a post-Kyoto decision. Future scenarios at EU-level highlight a deficit of wood supply compared to wood consumption of $47 \mathrm{Mm}^{3}$ in $2005,134 \mathrm{Mm}^{3}$ in 2010 , possibly reaching $436 \mathrm{Mm}^{3}$ in 2020 (COST 4137/10 2010). The major issues to be clarified were the potential supply of tree biomass, trees outside the forest, and the economic, social and ecological conditions, which will determine the wood supply.

The objectives of the COST Action were to:

1. Improve and harmonize data and information on the potential supply of wood resources at European level

2. Compare and disseminate the methodologies, including remote sensing techniques, definitions and results of wood resource studies in European countries and develop best practices and harmonized guidelines in this field

3. Exchange information on difficulties and challenges and find harmonized solutions in, e.g. modelling taper curves and assortments of trees or in assessing trees outside forests

4. Help countries to improve their expertise in special modelling or remote sensing techniques in capacity building of these technical areas

5. Contribute to build a comprehensive and reliable picture of potential wood supply as an input to energy, 
environment, forest policy making, and wood industry decision making

\subsection{Framework contract between ENFIN and the JRC}

The published methodologies of building reference definitions and bridges to enhance harmonization opened up the possibility to produce harmonized data at EU level. These methodologies were applied by the JRC in setting up the harmonized EU forest database. In this respect, the JRC launched a 4-year Framework Contract (FC) for provision of forest data and services in 2007. This FC was opened to European countries on a voluntary basis. A consortium of ENFIN members answered and was successful in securing this contract. The main outputs of this first FC were:

(i) The provision of harmonized data on tree species distribution on a $1 \mathrm{~km} \times 1 \mathrm{~km}$ INSPIRE grid over Europe with a joint JRC-ENFIN publication of a European tree species atlas (San Miguel Ayanz et al. 2016);

(ii) The validation of the JRC European forest map with more than 2 million NFI forest/non-forest plots;

(iii) A harmonized basal area statistical estimation based on the $50 \mathrm{~km} \times 50 \mathrm{~km}$ INSPIRE grid with a satisfactory confidence interval.

Under the leadership of the French NFI, an intermediate data platform (called e-forest) was developed to gather NFI plot data at the European scale. This intermediate platform was necessary to allow NFI experts to upload data which was linked by a confidentiality agreement. The platform was used to generate statistics whenever a new request was received from the EC. This permitted the provision of sound aggregated harmonized results to the European Commission, crossing national borders. A second FC was signed at the end of 2011 in order to continue the data provision service to the JRC on a voluntary basis. Results include an open source dynamic model to estimate volume and growing stock as well as forecasts under forest management hypotheses applicable under different climatic and forest management conditions all over Europe (Sallnäs et al. 2015). In addition, a harmonized method to calculate biomass based on the INSPIRE grid is currently being prepared by a large majority of EU countries.

\subsection{Horizon 2020}

Horizon $2020(\mathrm{H} 2020)$ is the financial instrument implementing the Innovation Union, a Europe 2020 flagship initiative aimed at securing Europe's global competitiveness.
Under the H2020 call, two specific lines are devoted to forests, the first one is to harmonization of forest data and the second one is to improve forest management models. These research calls are launched to support EU policies, highlighting the importance of harmonized data at EU level for both calls. The ENFIN group associated with a large consortium of Universities and Research Institutions from 25 European countries under the leadership of Natural Resources Institute Finland proposed a project called DIABOLO and won the first call (H2020 grant agreement No. 633464). This 4-year research project will build on the results and publications of COST Action E43 and FP1001 to develop new scientific methods for the harmonization of data.

\section{Discussion and conclusions}

Europe is probably one of the most complex areas in the world to collect harmonized forest information. Through many years of experience, European countries have developed NFIs, forest information databases and systems that collect and analyze this information at a national scale. However, when looking at forest resources at a European level, differences in forest definitions, methods and scope of the information systems reveal a very complex network made of national and regional systems, which makes the collection of harmonized information a difficult task (Table 1). This long experience gave ENFIN the opportunity to play a precursor role in developing tools and methods for harmonization. At EU level, a series of "Data Centres" were defined in 2005, giving the JRC the responsibility for developing and establishing the European Forest Data Centre (EFDAC). However, without an underlying European forest policy, the collection and reporting of detailed forest information from the countries is often difficult due to incomplete datasets because of the voluntary basis of MS contributions. Although very valuable, reporting in this context provides a single value for each forest variable for each country, which limits the type of analysis that can be done with this information. There is a long way to achieve harmonization for all attributes, but with the first results achieved, the road is paved for future harmonization work. ENFIN plays an important role for all international reporting processes. Together with the COST Office and the JRC from the EC, NFIs have built reference definitions (Vidal et al. 2008), bridges to convert national data into comparable ones (Ståhl et al. 2012) and then tested this methodology in real situations (Tomter et al. 2012). This way of working could be a harmonization benchmark for UN regions of the world outside Europe with the ambition to be as closed as possible in terms of definitions between the different regions to enhance comparability within and among regions.

The European Forest Fire Information System (EFFIS) has been able to gather together most of the European countries 
for harmonized reporting on forest fire information. Using this as a model, the EC proposed to the Standing Forestry Committee (advisory committee of the EU Member States), the development of a similar system for the provision of forest information at the European level: the so-called Forest Information System for Europe (FISE) (San Miguel Ayanz et al. 2005). The FISE was developed in close collaboration between the JRC and the NFI data providers. The EC would encompass a series of modules collecting and analyzing information on, e.g. forest disturbances (biotic and abiotic), forest resources, forest biodiversity and forest and ecosystem services. It will be the basis for forest resource analysis and modelling at European level. The development of the FISE is foreseen in the context of the EU Forest Strategy (EC 2013). To achieve this goal and ensure a close cooperation between the JRC and MS, a European Forest Bureau Network (EFBN) would be established. NFIs have an important contribution to make in this bureau and in the harmonization process (Fig. 3).

The sustainable supply of wood, in the context of an increased use of wood together with UNFCCC commitments, is challenging. The concept of SFM is not readily grasped and so is difficult to define. Intergovernmental agreements such as those of the Montréal Process and Forest Europe, introduced C\&I for assessing SFM. Unfortunately, the Montréal Process and Forest Europe do not use the same set of C\&I, as data collected through the two exercises in temperate and boreal forests are hardly comparable. NFI data are indeed crucial, but the most complete assessment of forests and SFM is achieved when they are integrated with information from other sources so that the social, environmental and economic dimensions can all be assessed. While NFIs are not providing all the data for C\&I reporting, many NFIs are responsible for putting together all the necessary information and being the

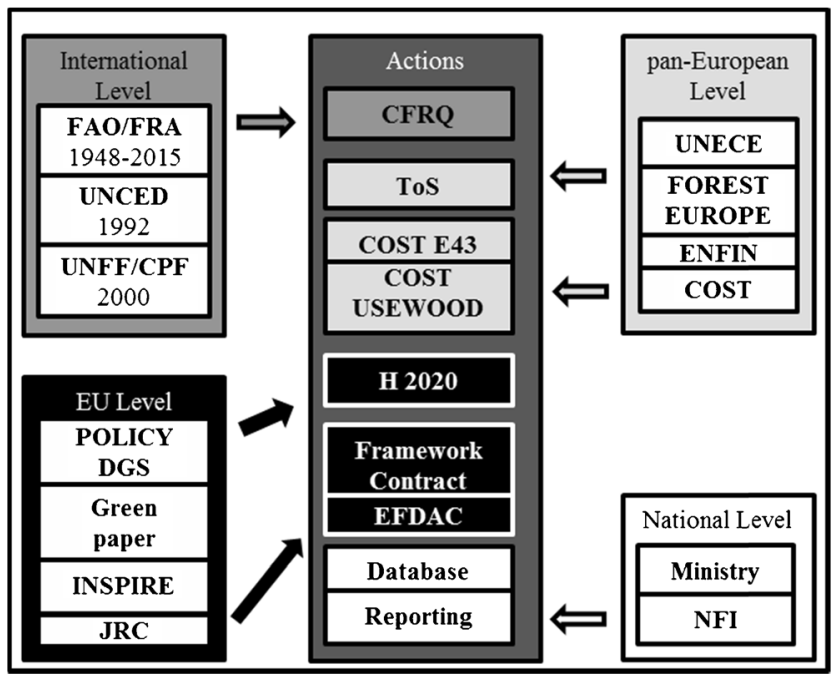

Fig. 3 Actions and actors of the harmonization process at different levels. Arrows symbolise the direct link between organizations in charge of the maintenance of each process correspondent to this C\&I process. Generally, NFIs are also in charge of data analysis for monitoring SFM.

Moreover, a lot of countries do not have sufficient means to properly assess SFM. The NFIs and other investigation methods/surveys (if any) are based on quantitative analytical variables. Nevertheless, to assess SFM, it is necessary to define more global C\&I. The choice of such C\&I is subjective and that leaves to countries room for interpretation. There is currently no common agreement at world level nor at European level on how to assess SFM. There is, for example, a lot of criticism on the usefulness of the set of C\&I developed by Forest Europe to assess SFM (Baycheva et al. 2013).

Tackling today's environmental challenges, such as adapting to climate change, managing ecosystems and natural resources in a sustainable manner, protecting biodiversity, preventing and managing environmental crises such as floods, forest fires, storms and water scarcity, depend on the assessment of data from a variety of sectors and sources.

Lessons learnt on the complexity of international reporting highlight that close cooperation between providers of information represented at European level by ENFIN is an important step towards harmonization. The research, networking and demonstration projects conducted by ENFIN must be continued and supported by financed initiatives in order to speed and enlarge the scope of the harmonization possibilities. However, there are remaining indicators requested for international (such monitoring the evaluation of the conservation status of Natura 2000 in forest habitats, the estimation of nonwood forest products production) for which more efforts are needed and harmonization process is ongoing by NFI experts (DIABOLO project). ENFIN and NFI experts should also be engaged as early as possible in the political processes, particularly for the definition of new criteria and indicators.

This example of a European way of working by structuration of research actions and pilot studies to test harmonization possibilities among NFIs, as well as the necessary dialogue between policy makers and providers of information prior to setting up new information and/or criteria and indicators could be a benchmark for other UN regions of the world in order to enhance dialogue and comparability of data for international reporting. In a period where forest policy requirements are changing quickly, this close collaboration between policy makers and providers of information is essential to obtain a clear and comparable picture of forests among countries in order to take decisions. It is also a key element for addressing a number of issues: demand for renewable energy, evaluating the impact climate change on forests or the ever increasing numbers of natural hazards. It is not clear what form this close cooperation between policy makers and providers will take. However, following this collaborative process, NFIs will be in a better position to anticipate new policy needs, discuss possible solutions together and with policy makers to propose a 
sound and common response to these new needs as quickly as possible, backed up with comparable relevant data.

Acknowledgments We would like to thank the Vice chair of the Cost Action Susana Barreiro and the previous Chair Annemarie Batstrup-Birk for their efficient coordination and all NFI experts who collaborating in the COST Action FP1001 and Tracy Houston Durrant for her professional English review.

Funding This research was supported by the COST Action FP1001.

\section{References}

Alberdi I, Condés Ruiz S, Millán JM, de Saura Martínez TS, Sánchez Peña G, Pérez Martín F, Villanueva Aranguren J, Vallejo Bombín R (2010) National Forest Inventory Reports-Spain. In: Tomppo E et al (eds) National Forest Inventories - pathways for common reporting. Springer, Heidelberg, Dordrecht, London, New York, pp 529-540

Alberdi I, Cañellas I, Condés S (2014) A long-scale biodiversity monitoring methodology for Spanish National Forest Inventory. Ann For Sci 23:93-110

Barthod C, Touzet G (1994) De Strasbourg à Helsinki: les deux premières Conférences Ministérielles pour la Protection des Forêts en Europe. Revue Forestière Francaise XL

Baycheva T, Inhaizer H, Lier M, Prins K, Wolfslehner B (2013) Implementing criteria and indicators for sustainable forest management in Europe. European Forest Institute.

Blackard JA, Finco MV, Helmer EH, Holden GR, Hoppus ML, Jacobs DM, Lister AJ, Moisen GG, Nelson MD, Riemann R, Ruefenacht B, Salajanu D, Weyermann DL, Winterberger KC, Brandeis TJ, Czaplewski RL, McRoberts RE, Patterson PL, Tymcio RP (2008) Mapping U.S. forest biomass using nationwide forest inventory data and moderate resolution information. Rem Sen Env 112:1658-1677

Canadian Forest Service (1997). The Montreal Process Progress Report. Ottawa

Castaneda F. (2000) Criteria and Indicators for Sustainable Forest Management: international processes, current status and the way ahead. Unasylva 203(51)

CBD, 2010. COP 10 Decision X/2. Strategic plan for biodiversity 20112020. Conference of the Parties of the Convention on Biological Diversity. Nagoya, Japan, 18-29 October 2010. Available online at www.cbd.int/decision/cop/?id12268. Accessed 13 February 2015

Chirici, G, Winter S, McRoberts R E (Eds.) (2011) National Forest Inventories: Contributions to Forest Biodiversity Assessments. SPRINGER.Managing Forest Ecosystems 20- ISBN 978-94-0070482-4

Chirici G, McRoberts RE, Winter S, Bertini R, Brändli UB, Asensio IA, Bastrup-Birk A, Rondeux J, Barsoum N, Marchetti M (2012) National forest inventory contributions to forest biodiversity monitoring. For Sci 58:257-268

COST 4137/10 (2010) Memorandum of understanding for the implementation of a European Concerted Research Action designated as COST Action FP1001 USEWOOD: improving data and information on the potential supply of wood resources: a European approach from multisource national forest inventories. http://w3.cost.eu/ fileadmin/domain_files/FPS/Action_FP1001/mou/FP1001-e.pdf. Accessed 10 October 2014

de Foresta H, Somarriba E, Temu A, Boulanger D, Feuilly H, Gauthier M (2013) Towards the assessment of trees outside forests Thematic report GFRA- IRD/FAO

Dolman A J, Valentini R, Freibauer A. Ed (2013) The continental-scale greenhouse gas balance of Europe. SPRINGER.
EC (2009) European Commission COM 2009. 147 final-White paper on adapting to climate change: towards a European framework for action. http://eur-lex.europa.eu/LexUriServ/LexUriServ.do?uri= COM:2009:0147:FIN:EN:PDF. Accessed 13 February 2015

EC (2010) Report on the stakeholder consultation concerning the Commission Green Paper on forest protection and information. COM (2010)66fin.

EC (2012). Standing Forestry Committee. Ad hoc working group on forest information and monitoring. Final report. "Forest information needs, required resources, ways and means". http://ec.europa.eu/ agriculture/fore/publi/sfc-wg6-2012_en.pdf. Accessed 3 October 2015

EC (2013) European Commission, COM 2013. 659 final. A new EU forest strategy: for forests and the forest-based sector. http://eurlex.europa.eu/legal-content/EN/TXT/PDF/?uri= CELEX:52013DC0659. Accessed 13 February 2015

EEA (2012) Environmental indicator report 2012 European Parliament B7-0571/2011. Resolution of 11 May 2011 on the green Paper on Forestry, COM 2010) 66 final. http://www.europarl.europa.eu/sides/ getDoc.do?pubRef=-//EP//TEXT+MOTION+B7-2011-0571+0+ $\mathrm{DOC}+\mathrm{XML}+\mathrm{V} 0 / / \mathrm{EN}$. Accessed 13 February 2015

FAO (1948) Unasylva. 2(4) Forest resources of the world http://www.fao. org/docrep/x5345e/x 5345e 00.htm\#Contents. Accessed 13 February 2015

FAO, JRC (2012) Global Forest Land use Change 1990-2005-FAO Forestry Paper No. 169

Ferretti M (2010) Futmon QAC Status Report 1. Status of forest monitoring method harmonization in Europe. http://www.futmon.org/ sites/default/files/documenten/Report_QAC.pdf Accessed 13 February 2015

Food and Agriculture Organization. (1995). Forest resources assessment 1990. Global synthesis. FAO.

Forest Europe (2011) European 2020 targets for forests and launching negotiations for a legally Binding Agreement. General declaration Oslo 2011

Forest Europe, UNECE and FAO (2011). State of Europe's Forests 2011. Status and Trends in Sustainable Forest Management in Europe.

Forest Europe, UNECE and FAO (2015) State of Europe's Forests 2015. FOREST EUROPE Liaison Unit Madrid, Spain

FRA 2000 (2000). On definitions of forest and forest change. http://www. fao.org/docrep/006/ad665e/ad665e00.htm. Accessed 13 February 2015

FRA 2015 (2012). Terms and definitions. http://www.fao.org/docrep/ 017/ap862e/ap862e00.pdf. Accessed 13 February 2015

Gabler K, Schadauer K, Tomppo E, Vidal C, Bonhomme C, McRoberts RE, Gschwantner T (2012) An enquiry on forest areas reported to the global forest resources. Assessment - is harmonization needed? For Sci 58:201-213

Gold S, Korotkov AV, Sasse V (2006) The development of European forest resources, 1950 to 2000. Forest Policy Econ 8:183-192

Gong P, Wang J, Yu L, Zhao Y, Liang L, Niu Z, Huang X, Fu H, Liu S, Li C, Li X, Fu W, Liu C, Xu Y, Wang X, Cheng Q, Hu L, Yao W, Zhang H, Zhu P, Zhao Z, Zhang H, Zheng Y, Ji L, Zhang Y, Chen H, Yan A, Guo J, Yu L, Wang L, Liu X, Shi T, Zhu M, Chen Y, Yang G, Tang P, Xu B, Giri C, Clinton N, Zhu Z, Chen J, Chen J (2013) Finer resolution observation and monitoring of global land cover: first mapping results with Landsat TM and ETM+ data. Int J Rem Sen 34:2607-2654

Grainger A (2008) Difficulties in tracking the long-term global trend in tropical forest area. Proc Natl Acad Sci USA 105:818-823

Gschwantner T, Schadauer K, Vidal C, Lanz A, Tomppo E, di Cosmo L, Robert N, Englert- Duursma D, Lawrence M (2009) Common tree definitions for national forest inventories in Europe. Sil Fenn 43: 303-321

Hansen MC, Stehman SV, Potapov PV (2010) Quantification of global forest cover loss. Proc Natl Acad Sci USA 107:8650-8655 
Hansen MC, Potapov PV, Moore R, Hancher M, Turubanova SA, Tyukavina A, Thau D, Stehman SV, Goetz SJ, Loveland TR, Kommareddy A, Egorov A, Chini L, Justice CO, Townshend JRG (2013) High-resolution global maps of 21st-century forest cover change. Sci 342:850-853

Johnson S (1993) The Earth Summit: The United Nations Conference on Environment and Development (UNCED). Graham and\& Trotman/ Martinus Nijhoff, London

Keenan RJ, Reams G, Achard F, de Freitas JV, Grainger A, Lindquist E (2015) Dynamics of global forest area: results from the FAO Global Forest Resources Assessment 2015. For Ecol Man 352:9-20

Keith H, Mackey BG, Lindenmayer DB (2009). Re-evaluation of forest biomass carbon stocks and lessons from the world's most carbondense forests Communicated by Gene E. Likens, Cary Institute of Ecosystem Studies, www.pnas.org/cgi/content/full/0901970106/ DCSupplemental. Accessed 10 September 2015.

Kelatwang S (2002) South Africa's view on linkage between national information needs and international reporting requirements. Kotka IV presentation. METLA-FAO Acts

Killmann W.and Schöne D (2003) Principles and process of harmonising forest related definitions for use by various stakeholders. XII World Forestry Congress Acts. Quebec 2003

Lanz A, Alberdi I, Barbati A, Barsoum N, Brändli U-B, Chirici G, Cienciala E, Condes S, Di Cosmo L, Freudenschuss A, Gabler K, Gschwantner T, Hylen G, Ilvesniemi H, Kusar G, Kändler G, Lawrence M, McRoberts RE, Nabuurs G-J, Petersson H, Priwitzer T, Robert N, Rondeux J, Schadauer K, Ståhl G, Tomter S, Tomppo E, Tosi V, Vidal C, Weiss P, Winter S (2010) A sample of Cost Action E43 reference definitions. In: Tomppo E, Gschwantner T, Lawrence M, McRoberts RE (eds) National Forest Inventoriespathways for common reporting. Springer, New York, pp 595-607

Matthews E (2001) Understanding the FRA 2000-World Resources Institute-Forest briefing No. 1 (www.wri.org)

Matthews E., Grainger A. (2002) Evaluation of FAO' Global Forest Ressources Assessment from the user perspective. Unasylva 210, Vol 53

Mc Donald GT, Lane MB (2004) Converging global indicators for sustainable forest management. Forest Policy Econ 6:63-70

MCPFE (1998) Third Ministerial Conference - General declarationLisbon 2-4 June 1998

MCPFE, (2003) Vienna Living Forest Summit Declaration: European Forests - Common benefits, shared responsibilities.

McRoberts R E; Reams G A, Van Deusen P C, McWilliams W H (2009). Bridging the gap between strategic and management forest inventories. In: eds. Proceedings of the eighth annual forest inventory and analysis symposium; 2006 October 16-19; Monterey, CA. Gen. Tech. Report WO-79. Washington, DC: U.S. Department of Agriculture, Forest Service. 279-287.

McRoberts RE, Tomppo E, Schadauer K, Ståhl G (2012) Harmonising National Forest Inventories. For Sci 58:189-190

Mohammadi Fazel A, Gibson J, Harrison J, Herkenrath P, Kelly J (2015) A process for identifying national solutions to challenges faced in developing countries in reporting to environmental conventions: insight from the facilitating national reporting to the Rio conventions project. Int J Environ Res 9:1163-1172

Pereira HM, Ferrier S, Walters M, Geller GN, Jongman RHG, Scholes RJ Bruford MW, Brummitt N, Butchart SHM, Cardoso AC, Coops NC, Dulloo E, Faith DF, Freyhof J, Gregory RD, Heip C, Höff R, Hurtt G, Jetz W, Karp DS, McGeoch MA,Obura D, Onoda Y, Pettorelli N, Reyers B, Sayre R, Scharlemann JPW, Stuart SN, Turak E, Walpole M, Wegmann M (2013) Essential biodiversity variables-Science 339(6117):277-278
Putz FE, Redford KH (2010) The importance of defining forest; tropical forest degradation, deforestation, long-term phase shifts and further transition. Biotropica 42:10-20

UN Rio Conference (1992) - http://www.unesco.org/education/ nfsunesco/pdf/RIO_E.PDF. Accessed 14 February 2015

Romijn E, Lantican CB, Herold M, Lindquist E, Ochieng R, Wijaya A, Murdiyarso D, Verchot L (2015) Assessing change in natioanl national forest monitoring capacities of 99 tropical countries. For Ecol Man 352:109-123

Rondeux J, Bertini R, Bastrup-Birk AM, Corona P, Latte N, Mc Roberts RE, Stahl G, Winter S, Chirici G (2012) Assessing deadwood using harmonized NFI data. For Sci 58:269-283

Sallnäs O, Berger A, Räty M, Trubins R (2015) An area-based matrix model for uneven-aged forests. Forests 6:1500-1515

San Miguel Ayanz J, Flies R, Seoane I (2005) Towards a forest information system for europe-Proceedings of the 16th Internatianl Workshop on database and Expert systems Applications (DEXA'05) - IEEE

San Miguel Ayanz J. et al. (2016). European Atlas of Forest Tree Species. Eds. Publication Office of the European Union, Luxembourg. ISBN: 978-92-79-36740-3.

Ståhl G, Cienciala E, Chirici G, Lanz A, Vidal C, Winter S, McRoberts RE, Rondeux J, Schadauer K, Tomppo E (2012) Bridging National and Reference Definitions for Harmonising Forest Statistics. For Sci 58:214-223

The World Bank (2008) Forest Sourcebook: practical guidance for sustaining forests in development cooperation - Collection Agriculture and Rural development.

Tomppo E, Gschwantner T, Lawrence M, McRoberts RE (eds.) (2010) National Forest Inventories. Pathways for common reporting. Springer.

Tomppo E, Schadauer K, McRoberts RE, Gschwantner T, Gabler K, and Ståhl G (2010) Introduction. In: National Forest Inventories Pathways for Common Reporting. In Tomppo E, Gschwantner T, Lawrence M, McRoberts RE, (eds). Springer, pp 597-609.

Tomter SM, Gasparini P, Gschwantner T, Hennig P, Kulbokas G, Kuliešis A, Polley H, Robert N, Rondeux J, Tabacchi G, Tomppo E (2012) Establishing bridging functions for harmonising growing stock estimates: examples from European National Forest Inventories. For Sci 58:224-235

Trumper K, Ravilious C, Dickson B (2008). Mitigating climate change in drylands. The case for financing carbon sequestration. Assessment technical note for discussions at CRIC 7, Istanbul, Turkey, November 2008. UNEP-WCMC: http://www.unep.org/pdf/carbondrylands-technical-note.pdf. Accessed 14 February 2015

UN 1992: Convention on biological diversity https:/www.cbd.int/doc/ legal/cbd-en Accessed 10 September 2015.

UNECE/FAO (2000) Temperate and Boreal Forest Resources 1272 Assessment of 2000 Main report. http://www.unece.org/forests/fra/ pdf/contents.htm. Accessed 10 October 2014.

UNFCCC (2009) United Nations Framework Convention on Climate Change. http://unfccc.int/657 2860.php. Accessed 10 September 2015.

Vidal C, Lanz A, Tomppo E, Schadauer K, Gschwantner T, Di Cosmo L, Robert N (2008) Establishing forest inventory reference definitions for forest and growing stock: a study towards common reporting. Silva Fen 42:247-266

Winter S, Chirici G, Mc Roberts RE, Hauk E, Tomppo E (2008) Possibilities for harmonizing NFI data for use in forest biodiversity assessments. Forestry 81:33-34

Winter S, McRoberts R E, Chirici G, Bastrup-Birk A, Rondeux J, Brändli U B, Nilsen J O, Marchetti M. (2011) The need for harmonized estimates of forest biodiversity indicators. In National Forest Inventories: Contributions to Forest Biodiversity Assessments (pp. 1-23). Springer Netherlands. 